\title{
Internal Capital Markets and Patenting in Emerging Growth Firms
}

\author{
Richard Ebil Ottoo ${ }^{1}$, Maurice Larrain ${ }^{1} \&$ Anthony Joseph ${ }^{2}$ \\ ${ }^{1}$ Lubin School of Business, Pace University, New York, USA \\ ${ }^{2}$ Seidenberg School of Computer Science, Pace University, New York, USA \\ Correspondence: Richard Ebil Ottoo, Department of Finance and Economics, Lubin School of Business, Pace \\ University, One Pace Plaza, New York, NY 10038, USA. Tel: 1-212-618-6526. E-mail: rottoo@pace.edu
}

Received: July 5, 2013

Accepted: July 30, 2013

Online Published: August 26, 2013

doi:10.5539/ijef.v5n9p96

URL: http://dx.doi.org/10.5539/ijef.v5n9p96

\begin{abstract}
Despite the overwhelming theoretical intuition in support of the arguments that internally generated capital should be an important determinant of corporate innovation, very little empirical evidence of this association has been established. In this paper we show that internal capital markets have a positive and significant relationship with patenting of emerging firms. However, for mature firms, the relationship between internal finance and patenting is negative but not significant. Our empirical analysis is grounded on the theoretical modeling of granting a patent as the maturity date of an American real call option, with internal capital and R\&D expenses serving to shorten the maturity of the growth option and to speed up innovation.
\end{abstract}

Keywords: investment decision, internal capital markets, firm value, patenting, R\&D, innovation, emerging firms

\section{Introduction}

It is universally recognized that innovation is an important source of economic growth and development. At the firm level continual innovation is often the key to corporate growth and competitiveness. There is a general presumption that patents are useful to encourage innovation despite the market distortions of the monopolies that they create. In most high-technology industries, for instance, pharmaceuticals, computer software and biotechnology, firms must "innovate or perish." The purpose of this study is to examine the impact of internal capital markets on the innovative activities of firms. In particular, we focus on emerging firms, which are especially affected by imperfections in external financial markets and so suffer disproportionately a disadvantage in accessing outside capital.

Several studies have demonstrated the information asymmetry of R\&D investments for new product developments (e.g., Myers \& Majluf, 1984; Stein, 1988). Inside managers have more information about the projects than outside investors do and are often reluctant to reveal "too much." However, an original idea must be financed in order for it to have a chance to eventually break-through. Inside managers have the option to tap external or internal capital. When approached for funding, outside investors have a tendency to ration funds because of the belief that insiders overstate the prospects of the projects. This has the benefit of preventing overinvestment (when the true state of the world is "bad") but it also has the cost of causing underinvestment (when the true state of the world is "good"). This financing problem may be modest for mature firms but it is critical for young and emerging firms whose individual projects would find it hard to attract external financing. The objective of this study is to empirically test the implications of those circumstances under which internal capital markets would tend to be the most effective mode of financial arrangement.

Financial economics literature on the theories of internal capital markets has focused mainly on two opposing views. According to the bright side of internal capital markets discussed by Alchian (1969), Weston (1970), Williamson (1975), Gertner, Scharsftein, \& Stein (1994), Stein (1997), Matsusaka \& Nanda (2002), and Maksimovic \& Phillips (2002), internally generated cash flows are pooled and subsequently allocated optimally to divisions or units of the firm. In this winner-picking model, internal capital markets add value and benefit the firm since the allocation is mainly justified by the presence of investment opportunities. Managers whose units have greater investment opportunities ultimately should receive larger allocations of internal capital. The dark side argument, however, claims that internal capital markets are strongly influenced and guided by internal political processes (e.g., Coase, 1937; and Bower, 1970). This view suggests that internal resource allocation 
would typically be inefficient since investment opportunities are not considered that much. In this model, managers who are more powerful or who are better connected to the CEO receive greater allocations even when their units do not have better investment opportunities (Milgrom, 1988; Milgrom \& Roberts, 1988; Sharfstein \& Stein, 2000; Rajan, Servaes, \& Zingales, 2000; and Wulf, 2009). In a recent survey study providing further support to this view, Graham, Harvey, \& Puri (2011) find that the opinion of a CEO of a divisional manager is the second most important determinant of capital allocation within the firm after the net present value rule. For a detailed survey of the literature on internal capital markets, see Stein (2003) and Maksimovic \& Phillips (2007).

While substantial progress has been made in theoretically modeling internal capital markets as reflected in the works cited above, not much is known empirically. Exceptions are Duchin \& Soyura (2013) and Glaser, Lopez-De-Silanes, \& Sautner (2013). Duchin \& Soyura (2013) study the role of divisional managers at S\&P 500 firms in internal capital budgeting and document evidence of strong negative correlation between managerial connection and investment efficiency but only under weak corporate governance. They also show that under high information asymmetry within the firm, connections facilitate information transfer which leads to increased investment efficiency and firm value. Glaser, Lopez-De-Silanes, \& Sautner (2013) analyze the internal capital markets of a multinational conglomerate and find evidence largely consistent with the prediction of the dark side view of internal capital markets. These studies are important because they document how, and under what circumstances, the interactions of the CEO with the divisional managers impact internal capital allocation. However, we are still left with relatively little knowledge about the effect of internal capital markets on investment opportunities. Do firms with larger internal capital markets produce more organic innovations, hence growth opportunities? Are the roles of internal capital markets uniform among emerging and well established firms in effecting innovation? In this paper, we seek to answer these questions with direct evidence from testing a theoretical valuation model of growth opportunities on a sample of emerging innovative U.S. manufacturing firms in comparison with mature corporations. We define an emerging firm as a relatively young company that has never issued dividends and has never acquired or merged with another firm.

Economists have argued that internally generated capital should be an important determinant of R\&D investments whose outputs are measured by the number of patents awarded or product and process improvements attained. Yet to date there has been relatively little empirical evidence of a relationship between internal capital markets and innovation. One recent exception is the work of Himmelburg \& Peterson (1994), which finds a substantial effect of internal finance on R\&D investments for small firms. One reason for the lack of evidence is that most research has examined mainly the growth strategy of large and diversified firms that have relatively fewer constraints in accessing external capital markets than young firms (e.g. Lamont, 1997); Stein, 1997; Shin \& Stulz, 1998; and Scharsftein \& Stein, 2000). The other explanation has to do with the difficulty in theoretically modeling growth opportunities to such a rigor that would support sound empirical analysis.

The main contribution of our paper is to empirically document the role of internal capital markets in funding investment opportunities. Moreover, we do this by presenting a testable theoretical valuation model of corporate growth opportunities. We consider a patent as a measure of the firm's success in financing innovative investments that are characterized by a high probability of failure. It is possible that patent counts may not accurately reflect corporate innovation for reasons of secrecy and dynamic competitive environments. However, in young firms and industries where product-oriented innovation is predominant, patenting is important (McGahan \& Silverman, 2001). Griliches (1981) suggests that both R\&D and patents are inputs of innovation. Cockburn \& Griliches (1988) find that in the absence of R\&D variables, past patents are significantly valuable. Ben-Zion (1984) explains that whereas not all patents result in the production of new profitable products, a firm's patents are relevant for other firms in the industry in the sense that they contribute to increased technical knowledge or indicate a potential for new lines of research. Austin (1993) shows that patents are useful as indicators of innovative output but may produce no value if they have been fully anticipated by the market. In comparison to these studies, the aim of this paper is, however, rather specific in scope and is simply to examine the impact of internal finance on the ability of a company to produce patentable innovations.

The paper is organized as follows. Section 2 presents and discusses the theoretical model of corporate growth opportunities. Section 3 describes the empirical design of the study and the data. Empirical analysis and discussion are provided in Section 4. Section 5 concludes.

\section{Theoretical Basis of the Study}

It is now apparent that the conditions under which the financing of a firm would not matter as hypothesized by Modigliani \& Miller (1958) do not hold in practice. The valuation in Modigliani and Miller is determined by the assumed ability of the acquired assets of the firm to generate earnings into the future. Due to relatively high ratio of 
intangible to tangible assets, and the high uncertainty governing the payoffs to intangible assets, the market value of an emerging firm is therefore not independent of its financial structure. For these companies, access to internal sources of financing, as in Myers' pecking order theory (1984) and Myers \& Majluf's benefit of financial slack (1984), become a binding constraint. According to the pecking order theory, firms are said to prefer available liquid assets (e.g. retained earnings) to finance their investments. This is followed in order of preference by debt, and last comes external equity financing. Diamond (1989) suggests that start-ups and emerging firms with little reputation have less access to debt than well-established firms. This is consistent with Jensen and Meckling (1976), Myers (1977) and Stulz (1990) who show that leverage is expected to be negatively associated with the extent of growth opportunities. Thus, for emerging firms if internal funds are lacking then there is no access to external capital either, and the firm fails to enter the strategic growth competition.

Recent advances in real options analysis have produced models that better capture the interaction between current financing and future growth opportunities. The models most relevant to our study include Myers (1977) and Ottoo (1998). In Myers (1977), R\&D is valued as a call option on a given set of future investment opportunities. In Ottoo (1998), granting a patent is a credible signal that the firm has won the competitive race to innovate, thereby creating a barrier for rival firms. Winning the race gives the firm the right, but not the obligation, to launch a new product into the market and capture the value of growth opportunities. The elegance of this model is that a firm gains access to productive technology only by successfully completing the basic R\&D project before any competitor, thereby procuring patent protection to secure access to expected monopoly rents. The value of growth opportunities, $G$, is modeled as a real American call option:

$$
G=\left[\frac{f(x)}{r+f(x)+f(y)}\right]\left[V N\left(d_{1}\right)-K N\left(d_{2}\right) e^{-r T}\right]
$$

where:

- $\quad V$ is the present value of the expected net cash flows from the new product launch;

- $K$ denotes the capital expenditure that must be incurred at time $T$ to manufacture the product and generate the potential cash flows;

- $T$ represents the time when the firm wins the competitive race to innovate and is granted a patent. It is also the maturity date of the real call option, the date at which the firm exercises the option to produce and capture growth opportunities. Algebraically, $T$ is a function of the $\mathrm{R} \& \mathrm{D}(x)$ of the firm as well as the $R \& D(y)$ of its rivals and is expressed as:

$$
T=\frac{f(x)}{[f(x)+f(y)]^{2}}
$$

where $f(x)$ and $f(y)$ are the hazard rates of success for the firm and the rivals, respectively;

- $r$ is the risk-free rate of interest;

- $\sigma^{2}$ is the variance or volatility of expected cash flow value, $V$;

- $N\left(\mathrm{~d}_{1}\right)$ is the cumulative standard normal density function, a probability weight equivalent to the inverse of the hedge ratio for $V$, where $\mathrm{d}_{1}=\frac{\ln \frac{V}{K}+\left(r+\frac{\sigma^{2}}{2}\right) T}{\sigma \sqrt{T}}$; and

- $\quad N\left(\mathrm{~d}_{2}\right)$ is the cumulative standard normal density function, which denotes the probability that the real call option will be exercised (the option will finish in-the-money), i.e., $V>K$ ) and $\mathrm{d}_{2}=\mathrm{d}_{1}-\sigma \sqrt{T}$.

It is evident that each of the competing firms has an incentive to speed up discovery, which is a function of both financial prowess and technological (competitive) advantage. It follows that for an emerging firm, a shorter maturity date $(T)$ is consistent with a higher ability to patent, which depends on sufficient availability of internal funds, leading to increased market capitalization.

\section{Empirical Design}

The preceding theoretical exposition and intuitive description show that patenting may be influenced by a number of factors. In a functional form, we may present the relationship as

$$
P=f\left(\text { Internal Capital, } x, y, K, V, G, \sigma^{2}\right. \text {, Control Variables) }
$$




\subsection{Cross-sectional Regression}

We conduct cross-sectional regressions, year by year and across firms, following Fama \& MacBeth (1973). The final form of the least-squares regression equation expresses patents, $P$, as the dependent variable:

$$
P=\gamma+\beta_{1} C F+\beta_{2} V+\beta_{3} K+\beta_{4} x+\beta_{5} y+\beta_{6} G+\beta_{7} \sigma+\beta_{8} D+\beta_{9} C F+\beta_{10} A G E+\beta_{11} H H+\beta_{12} L+\hat{e}_{t}
$$

where $\gamma$ is the intercept coefficient of the regression; $\beta_{1}, \beta_{2}, \ldots . \beta_{12}$, are the coefficients of the independent variables fully described below; and ê is the error term.

\subsection{Fama-MacBeth and Fama-French Methodology}

We use a cross-sectional regression approach proposed by Fama \& French (1997), following Fama \& MacBeth (1973), in determining influencing variables on the valuation of growth opportunities of a firm to verify our findings. The Fama-MacBeth regressions have the following form:

$$
P_{i, t}=\mu_{0}+\sum_{j=1}^{H} \mu_{j, t} F_{i, j, t}+e_{i, t} \text { for } i=1,2, \ldots \ldots, N_{\mathrm{t}}
$$

where $H$ is the number of explanatory variables, $N$ is the number of firms, and $F_{i, j, t}$ is the realization of explanatory factor $j$ for firm $i$ in year $\tau(\tau=1,2, \ldots \ldots, t)$. Our sample period remains 1987-1993. We test the null hypothesis that the time-series average of year-by-year regression slopes is zero. That is,

$$
\frac{\sum_{t=1} \mu_{j, t}}{T}=0 \text { for } j=1,2, \ldots \ldots ., t .
$$

A t-test that assumes normality and identical independent distribution (i.i.d.) of the regression slopes is conducted. The time-series average slope coefficients are divided by their standard errors and multiplied by the square root of the number of observations. Two sets of regressions are run for each panel, with excess firm value $P$, as dependent variable: (i) single variable regressions of their current, past and future changes without any control variable and (ii) full variable regressions controlling for the influence of the rest of other variables. Only the two-year variable changes are included in the analysis. We run single level regressions to first evaluate the effects of each variable on the dependent variable independent of influences from any control variable. Following Kothari \& Shanken (1992) and Fama \& French (1997), we include in each regression a two-year change in patenting activity, $\Delta P V_{t+2}=$ $\left(P_{t+2}-P_{t}\right) / A_{t}$, to absorb any noise induced by their unexpected changes. When the dependent variable is $P_{t}$, the single-level cross-section regression for $\mathrm{R} \& \mathrm{D}$, for example, is:

$$
P_{t}=\mu_{t}+\beta_{1} X_{t}+\beta_{2} \Delta X_{t+2}+\beta_{3} \Delta X_{t-2}+\beta_{4} \Delta P_{t+2}
$$

where $\mu_{t}$ is the intercept term, and $\beta_{1}, \ldots, \beta_{4}$ are regressor coefficients.

We then conduct a full level regression analysis to determine if each of the variables would still retain its power in explaining changes in growth opportunities, after controlling for all other variables including the noise term. We examine if the coefficients are not zero and their t-values to confirm our earlier results. The full-level regression is expressed as follows:

$$
\begin{aligned}
P_{t}= & \mu_{t}+\beta_{l} A G E_{t}+\beta_{2} \Delta A_{t+2}+\beta_{3} \Delta A_{t-2}+\beta_{4} \Delta S_{t+2}+\beta_{5} \Delta S_{t-2}+\beta_{6} G_{t}+\beta_{7} \Delta G_{t+2}+\beta_{8} P P_{t}+\beta_{9} x_{t}+ \\
& \beta_{10} \Delta x_{t+2}+\beta_{I l} \Delta x_{t-2}+\beta_{12} y_{t}+\beta_{13} \Delta y_{t+2}+\beta_{14} \Delta y_{t-2}+\beta_{15} K_{t}++\beta_{16} \Delta K_{t+2}+\beta_{17} \Delta K_{t-2}+\beta_{18} \alpha_{t}+ \\
& \beta_{19} L_{t}+\beta_{20} \Delta L_{t+2}+\beta_{21} \Delta L_{t-2}+\beta_{22} D_{t}+\beta_{23} \Delta D_{t+2}+\beta_{24} D_{t-2}+\beta_{25} C F_{t}+\beta_{26} \Delta C F_{t+2}+\beta_{27} \Delta C F_{t-2}+ \\
& \beta_{28} H H_{t}+\beta_{29} \Delta H H_{t+2}+\beta_{30} \Delta H H_{t-2}+\beta_{31} \sigma_{t}+\beta_{32} \Delta \sigma_{t+2}+\beta_{33} \Delta \sigma_{t-2}+\beta_{34} \Delta V_{t+2}
\end{aligned}
$$

\subsection{Description of Variables}

We define the relevant variables as follows: Our dependent variable, $P$, denotes the relative probability of innovation and is proxied by the number of patents divided by the industry number of patents. $P$ is scaled by the ratio of firm assets to industry assets. All variables are normalized by total assets unless otherwise specified. The relative excess capitalized market value is employed to proxy the value of growth opportunities. The market value of the firm $(M V)$ is composed of the value of assets already in place $(A)$ and the present value of growth opportunities $(G)$. The relative excess value of the firm is thus measured as the market value of common stock plus the book value of debt $(M V)$ minus the book value of assets $(A)$ normalized by assets $(A)$. We compute the market value of common equity as closing stock price times the number of shares outstanding. Replacement costs are difficult to value. We consider $\left(G_{t} / A\right)$ to proxy average Tobin's $\mathrm{Q}$ by using book assets as a proxy for replacement costs.

$V$ represents the expected innovation (monopoly) rents and is proxied by two variables. One is the growth rate of sales derived by applying a simple exponential trend regression of net sales. In the year-by-year cross-sectional 
regression, we instead use expected change to represent the growth rate of sales. For example, the expected change (value) in sales over the next one year is expressed as $\left(\left(\right.\right.$ Sales $_{2}-$ Sales $\left.\left._{1}\right) / A_{1}\right)$. The other variable is the Herfindhal-Hirschman index $(H H)$ calculated by expressing market share of each firm (using sales) in the industry as a percentage and summing up the squared terms. $K$, the strike price is estimated by the levels of capital expenditures; $x$ represents current R\&D spending and $y$ denotes rival $\mathrm{R} \& \mathrm{D}$ expenditures which is computed as $R \& D$ of the industry less R\&D of the firm. Project volatility, $\sigma^{2}$, is measured by the Chauvin \& Herschey (1993) methodology using the natural logarithm of the ratio of the 52-week high and low stock prices for each firm, an index that is proportional to the Garman \& Klass (1980) "ideal" volatility estimator. We choose this approach over equity beta estimation due to limitation of scope of data availability especially for emerging companies. $D$ denotes debt ratio, the sum of debt in current liabilities and long-term debt divided by total assets, scaled by the industry's debt ratio. $C F$ represents operating cash flow measured by operating income plus R\&D expenditures which is meant to proxy internal capital. Another variable used is $\Delta A$, the expected change in assets, a proxy for the net investment component of internal cash flows. $A G E$ represents the natural logarithm of the number of years the company has been in existence since it was established. And $L$ is a measure of labor productivity, the ratio of total output (net sales) to labor inputs (number of employees).

\subsection{Data Sources and Sample Design}

We first gather all active U.S. public firms with a record of R\&D spending from the Standard \& Poor's annual industrial and full coverage Compustat database. This first sample is restricted to companies within the industries with two-digit SIC codes 3000 through 3800 . We then eliminate any industry that does not turn up an emerging firm. The final range covers fabricated metals and parts (3400); industrial and commercial machinery and computer equipment (3500); electrical and electronics (3600); transportation equipment (3700); and measuring and controlling devices (3800).

The companies are then traced as to whether their R\&D efforts have turned up any patented innovations. Patent counts are collected from the U.S. Patent and Trademark Office (USPTO) patent database. The database contains bibliographic citations of U.S. patents assigned to individuals, private and public organizations and firms, from 1969 to the present. For our purpose, an entity is considered to have patented if the patent is issued to its subsidiary, division or to the parent firm itself. In most cases the USPTO database would not distinguish a subsidiary from a parent company. Mergers and acquisitions record and information on subsidiaries and divisions of these firms are assembled from several sources for verification purposes: the National Register Publishing's Directory of Corporate Affiliations, Dun and Bradstreet Directory, Walker's Corporate Directory of U.S. Public Companies, and CorpTech Directory of Technology Companies. USPTO also does not record assignees distinctly as private or public firms. We resolve this problem by cross-checking the CorpTech Directory whose listings identify private and public technology firms as well as foreign-owned companies. Firms that are not cited by USPTO from 1969 to end of 1995 are not included in the sample. As it turned out, all the companies excluded based on this criterion did not have adequate financial data in Compustat and would have again been disqualified.

This study covers the period from 1987 to 1995 . The final selection of 201 firms constitutes a sample that must have all years of financial data for the period 1987-1993. The two-year lag for financial relative to patent data described in the empirical design explains the cut-off dates of 1993 and 1995 for financials and patents, respectively. Year of incorporation (founding) is accessed from Disclosure, Dun and Bradstreet, and CorpTech Directories databases. The sample is further divided into two panels: established firms and emerging firms. A firm is classified as emerging if it had never issued cash dividends as of the end of 1993 and has never acquired or merged with any other firm. We set 1995 as the end-date for our study to coincide with the period in the U.S. before a flood of Internet patents began to emerge. Internet patents cover business processes and models that have created and continue to expand digital commerce. Early well known examples of Internet patents include Priceline.com's reverse auction model for purchasing airline tickets (filed in 1996) and Amazon.com's patent on the "one-click" technique merchandise ordering (filed in 1997). There has been intense debate as to who should capture the growth opportunities arising from competitive Internet innovation and whether a flurry of Internet-implemented processes and methods should qualify as patentable subject matter given the importance of the Internet as a rapidly growing commercial platform combined with concerns for an open and free Internet (Allison, Tiller, Zyontz, \& Bligh, 2012). While the inclusion of the Internet patents in our study would be of great interest, obtaining a reasonable sample size of emerging firms with many years of $R \& D$ and patent data for a meaningful statistical analysis would be problematic. We therefore decided to leave that for future research where we would attempt to extend our work and model the role of internal capital markets on the valuation of growth opportunities under a digital commercial platform. This explains our decision to mark the period cut-off date to 1995 and to limit the sample to the manufacturing industries listed above whose $R \& D$ and patent awards at the time bore no relation to the Internet. 


\subsection{Industry Classification}

Table 1 presents industry classification of the companies to be analyzed. A total of 201 firms make up the final sample of which 107 (53.23\%) are emerging and 94 (46.77\%) are established firms. Five major industries are formed according to the two-digit SIC codes. Electrical and Electronics industry accounts for the largest share of the sample with $40.30 \%$ of the companies followed by Measuring Instruments and Devices $(22.39 \%)$ and Industrial and Computer Equipment (21.89\%). The majority of emerging firms $(42.99 \%)$ are in the Electrical and Electronics industry. There is only one emerging company compared with 25 mature firms in the transportation industry, which includes automotive, aircraft and defense. The Measuring Instruments industry is fairly balanced, with 23 emerging and 22 mature firms, respectively.

Table 1 . Sample distribution by industry classification

\begin{tabular}{|c|c|c|c|c|c|}
\hline 2-Digit SIC & Industry & Emerging Firms & Mature Firms & Total & Percent \\
\hline 3400 & Fabricated Metals and Parts & 3 & 2 & 5 & 2.49 \\
\hline 3500 & $\begin{array}{l}\text { Industrial and Computer } \\
\text { Equipment }\end{array}$ & 34 & 10 & 44 & 21.89 \\
\hline 3600 & Electrical and Electronics & 46 & 35 & 81 & 40.30 \\
\hline 3700 & Transportation & 1 & 25 & 26 & 12.94 \\
\hline 3800 & Measuring Instruments & 23 & 22 & 45 & 22.39 \\
\hline Total & & 107 & 94 & 201 & 100.00 \\
\hline
\end{tabular}

This table presents the classification of Industry by the two-digit Standard Industrial Classification (SIC) code. Only firms with financial data filed by Compustat and whose patents are cited in USPTO database are included.

\section{Empirical Analysis}

\subsection{Descriptive Statistics}

The descriptive statistics are presented in Table 2. Mature firms are relatively much older, with 1931 being their median year of founding compared with 1975 for emerging companies. Emerging firms on average employ 871 people, ranging from the smallest company with 19 to the largest company with 30,240. On the other hand, mature firms have a mean number of employees of 26,791 ranging from 68 to 354,508. Total assets of established firms are about 63 times larger $(\$ 4,975$ million with a standard deviation of $\$ 22,765$ million) than those of emerging firms ( $\$ 78$ million with a standard deviation of $\$ 208$ million). Mature firms also generate almost 52 times as much net sales as emerging firms, $\$ 4,217$ million against $\$ 81$ million. However, they have a much lower rate of growth in sales (4.94\%) than emerging firms (11.35\%). Emerging companies generally spend less on capital expenditures (\$8.03 million) and R\&D (\$9.39 million), compared to mature firms' capital expenditures ( $\$ 272.14$ million) and $\mathrm{R} \& \mathrm{D}$ (\$176.71 million). Mature companies experience lower levels of unanticipated changes (surprises) in capital expenditures (-15.94\%) than emerging firms $(-52.76 \%)$. On average, there are 3 patents procured by an emerging firm per year compared to 39 by a mature company (Table 2 and Figure 1). However, emerging firms do appear to outperform mature firms in generating the growth in patents granted (Figure 2). For each patent assigned, a mature firm spends $\$ 4.5$ million in $\mathrm{R} \& \mathrm{D}$. This is higher than the $\$ 2.9$ million incurred by an emerging firm (Figure 3).

Debt ratios don't appear to be significantly different between the two subsamples, $21.51 \%$ and $18.87 \%$ for mature and emerging firms, respectively. In terms of investment volatility, emerging companies are much riskier, with the natural logarithm of the ratio of the 52-week high to 52-week low of stock price of 0.422 compared to 0.267 for mature firms. Established companies enjoy higher levels of operating cash flows ( $\$ 492$ million) compared to that of emerging firms ( $\$ 13$ million). On average, emerging companies register a much higher ratio of excess value (growth opportunities) to book value of assets (61\%) than established companies (7\%). Mature firms tend to operate in more highly concentrated industries with a Herfindhal-Hirschman index of about 2200 while emerging companies are in more diffused industries at about a 1500 level of the same index. 
Table 2. Descriptive statistics for selected variables

\begin{tabular}{cccc}
\hline Variable & Emerging Firms & Mature Firms & All Firms \\
\hline Year Founded (median) & 1975 & 1931 & 1964 \\
Employees & 0.871 & 26.791 & 13.458 \\
& $(3.219)$ & $(87.533)$ & $(62.252)$ \\
Patents & 3.215 & 39.122 & 20.153 \\
& $(10.832)$ & $(91.468)$ & $(66.524)$ \\
Stock of Patents & 21.965 & 467.440 & 238.278 \\
& $(68.358)$ & $(1035.636)$ & $(755.208)$ \\
Net sales & 80.884 & 4216.591 & 2089.088 \\
& $(232.298)$ & $(15811.640)$ & $(11184.700)$ \\
Growth Rate of Sales & 11.354 & 4.943 & 8.241 \\
& $(23.378)$ & $(9.323)$ & $(18.226)$ \\
Total Assets & 78.160 & 4975.058 & 2455.981 \\
& $(208.248)$ & $(22764.980)$ & $(16012.520)$ \\
Capital Expenditures & 8.028 & 272.141 & 136.275 \\
& $(29.737)$ & $(1128.795)$ & $(795.932)$ \\
Surprise in Capital Exp. & -52.762 & -15.938 & -34.881 \\
& $(80.366)$ & $(28.160)$ & $(63.488)$ \\
R\&D Expenditures & 9.393 & 176.714 & 90.640 \\
& $(32.441)$ & $(665.688)$ & $(470.790)$ \\
Growth Rate of R\&D & 7.762 & 6.856 & 7.322 \\
& $(16.399)$ & $(13.182)$ & $(14.895)$ \\
Rival R\&D & 1987.139 & 4648.871 & 3279.615 \\
& $(1806.186)$ & $(4880.103)$ & $(3867.023)$ \\
Debt Ratio & 18.874 & 21.507 & 20.153 \\
& $(19.056)$ & $(14.312)$ & $(16.931)$ \\
Operating Cash Flow & 12.780 & 491.506 & 245.239 \\
& $(42.632)$ & $(1879.365)$ & $(1328.436)$ \\
Project Volatility & 0.422 & 0.267 & 0.347 \\
& $(0.116)$ & $(0.090)$ & $(0.130)$ \\
Herfindhal-Hirschman Index & 1521 & 2205 & 1853 \\
Growth Opportunities & 3.809 & -817.555 & -395.026 \\
& $(52.908)$ & $(10000.600)$ & $(6963.168)$ \\
\hline & & &
\end{tabular}

This table summarizes the time-series means of variables computed over the period 1987 to 1995 (standard deviation in parenthesis). Patents are in units. Employees are in thousands. Volatility of the growth option, Growth rates of sales and R\&D, debt ratio, HHI, and growth opportunities are all derived as explained under Section 3.3. "Surprise" is the unanticipated change in capital expenditures obtained by ordinary least squares by subtracting the actual from predicted percentage change. Rival R\&D is obtained by subtracting firm R\&D from industry R\&D. Net sales, operating cash flows, total assets, capital expenditures, R\&D, rival R\&D, operating cash flow and growth opportunities are in millions of dollars. Industry is classified by the two-digit SIC code. 


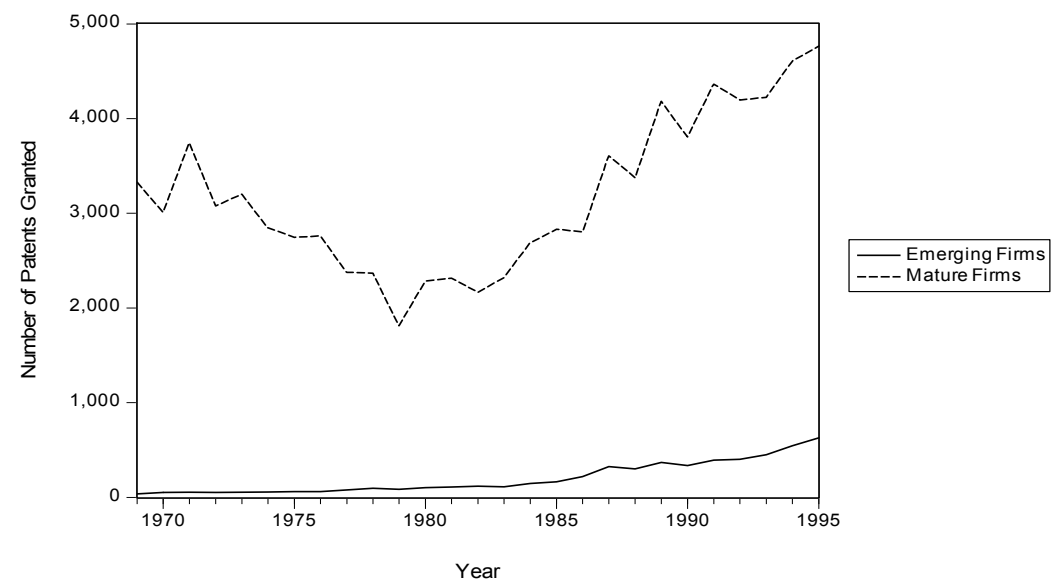

Figure 1. Number of patents granted annually to emerging and mature firms, 1969-1995

This figure plots comparable patent counts granted to emerging and mature firms over a twenty-seven year period.

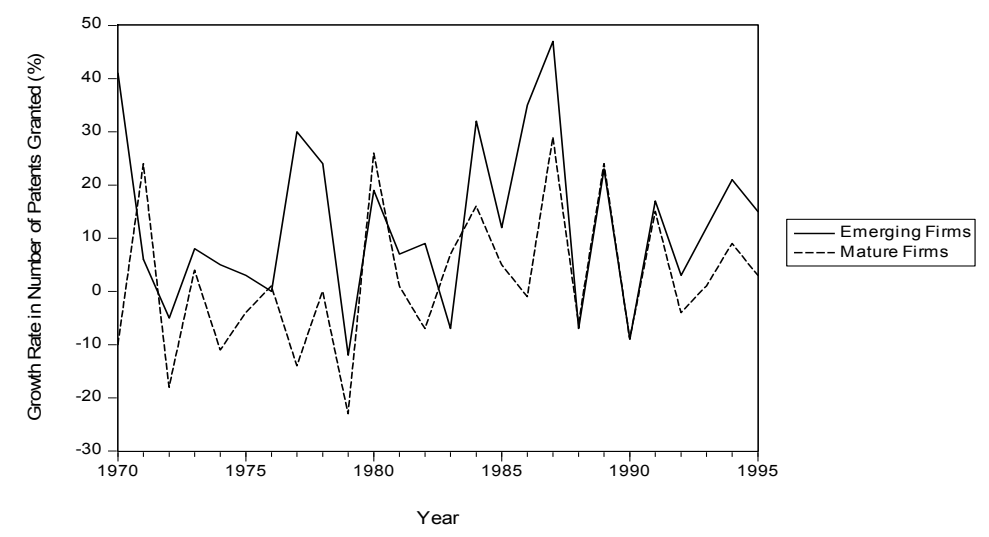

Figure 2. Annual growth rate in the number of patents granted to emerging and mature firms

This figure plots comparable annual growth rates in patent counts granted to emerging and mature firms over a twenty-seven year period, 1969-1995. 


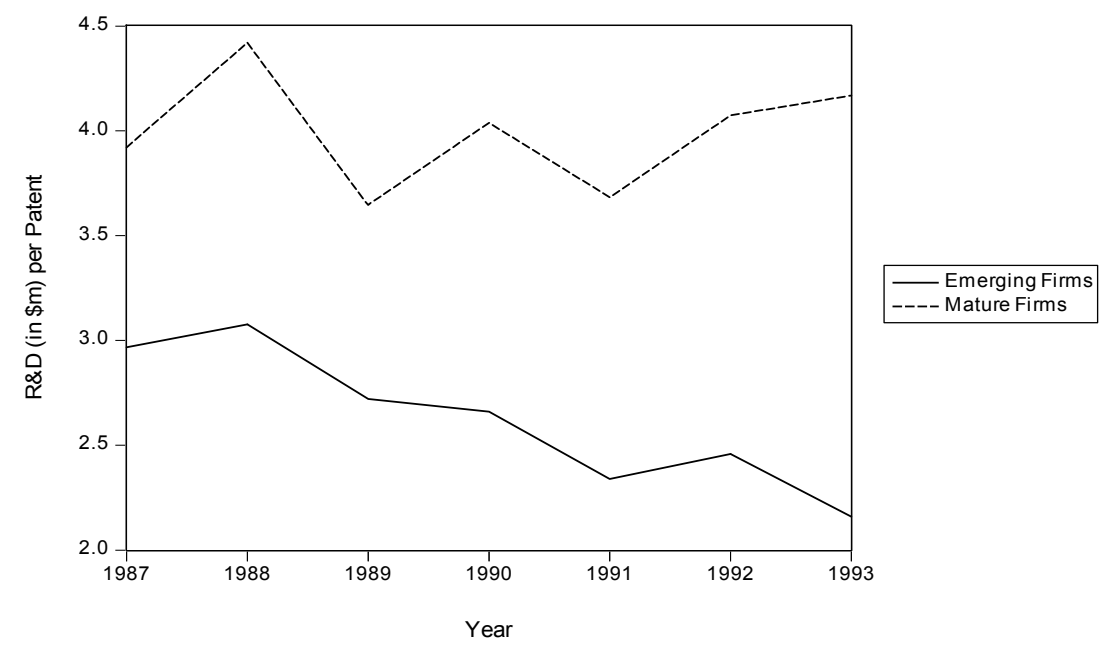

Figure 3. R\&D investments per patent granted in 1987 dollars (in millions)

This figure plots the ratio of investments in R\&D (in millions of dollars) per patent granted by year for both emerging and mature companies. R\&D expenses are computed in 1987 constant dollars.

\subsection{Empirical Results}

In Table 3 we present tests of significance of the mean difference of selected variables in the two sub-samples. Both t-tests and Wilcoxon non-parametric approximations are performed. The results are very similar employing both methods. We find 8 of the 14 variables (without their change components) considered to be significantly different between the emerging and mature firm groups. In particular, the difference in growth opportunities $\left(G_{t}\right)$ is highly significant, strongly supporting the hypothesis that emerging firms have distinctively larger real options than mature firms. On average, $63 \%$ of the market value of emerging firms compared to $6 \%$ for mature firms is accounted for by the present value of growth opportunities. Mean differences of stock of patents $(P P), \mathrm{R} \& \mathrm{D}(x)$, rival $\mathrm{R} \& \mathrm{D}(y)$, project risk $\left(\sigma_{\mathrm{v}}\right)$, capital expenditures $(K)$, operating cash flows $(C F)$, and industry concentration $(H H)$ are all significant. We infer that emerging firms are in high R\&D, less concentrated, and more volatile industries with less free-cash-flow and higher Tobin's $\mathrm{Q}$ ratio.

Cross-sectional regressions are then conducted. We regress current patents as the dependent variable and present results in Table 4. It is apparent that the impact and signs of some predictor variables in explaining the changes in the dependent variable do change from period to period. However, an overall picture of the power of a particular factor can be discerned. We find that the change in innovation, measured by the current number of patents $\left(P_{t}\right)$ is significantly explained by the stock of patents $\left(P P_{t}\right), \mathrm{R} \& \mathrm{D}\left(x_{t}\right)$, and research-in-progress as proxied by expected future changes in the number of patents $\left(\Delta P_{t+1}\right)$. Operating cash flows $\left(C F_{t}\right)$ and rival $\operatorname{R} \& \mathrm{D}\left(y_{t}\right)$ have greater impact on innovation in emerging than in mature firms.

One salient result is the influence of internal cash flows. For emerging companies, the net investment components of internal capital $\left(\Delta A_{t-1}\right.$ and $\left.\Delta A_{t+l}\right)$ are positive and significant. Current $\left(C F_{t}\right)$ and future values $\left(\Delta C F_{t+l}\right)$ of operating cash flows are significantly negative, and past values $\left(\Delta C F_{t-1}\right)$ are positive. These results strongly support our internal capital markets hypothesis and are consistent with the positive view of the internal capital markets theory (e.g., Alchian, 1969; Weston, 1970; Williamson, 1975; Gertner, Scharsftein, \& Stein, 1994; Stein, 1997; Matsusaka \& Nanda, 2002; and Maksimovic \& Phillips, 2002, among others). High Tobin's Q firms are high investment firms. And since for emerging companies investments must be financed internally, it implies that high Q emerging firms would have less cash flow left over after investments.

The negative sign of current operating cash flows for emerging firms also tends to support Jensen's (1986) assertion that after all positive net present value projects are considered and financed, and shareholders paid, the remaining "free cash flows" are often "wasted" by management. On the other hand, operating cash flows for mature firms are positive and highly significant, but the net investment component is negative for most of the sample period. The results for large firms are consistent with the managerial myopia hypothesis (Hayes \& Abernathy, 1980; Stein, 1988; Chandler, 1990; and Hitt, Hoskinson \& Ireand, 1990) and the dark side view of 
internal capital markets theory (Milgrom, 1988; Milgrom \& Roberts, 1988; Sharfstein \& Stein, 2000; Rajan, Servaes, \& Zingales, 2000; Wulf, 2009; and Glaser, Lopez-De-Silanes, \& Sautner, 2013, among others).

For emerging firms, capital expenditure $(K)$ signs are mixed, but generally show a negative relationship with growth opportunities in the two-year regressions. Unexpected values have positive signs in two of three regressions. Mature firms show a positive relationship of capital expenditures and their unexpected values with growth opportunities, overall. Volatility of the underlying investments $\left(\sigma_{v}\right)$ has a positive relationship in both subsamples for most of the study period. Debt ratio $(D)$ has a negative sign for emerging firms, but the signs are mixed for the established firms.

Table 3. T-tests and non-parametric comparisons of mean differences

\begin{tabular}{ccccc}
\hline Variable & Emerging Firms & Mature Firms & t-Statistic & Z-Statistic \\
\hline$\Delta \mathrm{A}$ & 0.0990 & 0.0735 & -0.5452 & 0.4076 \\
$\Delta \mathrm{S}$ & 0.1442 & 0.0814 & -1.2472 & -0.4889 \\
$\mathrm{P}$ & 2.5000 & 1.5403 & -1.3429 & 1.1848 \\
$\mathrm{PP}$ & 1.8119 & 1.8588 & 0.2132 & $2.1655^{* *}$ \\
$\mathrm{x}$ & 0.1302 & 0.0543 & $-5.7884^{* * *}$ & $-7.0179^{* * *}$ \\
$\mathrm{y}$ & 0.0707 & 0.0577 & $-5.1853^{* * *}$ & $-4.8589^{* * *}$ \\
$\mathrm{~K}$ & 0.0602 & 0.0607 & 0.0929 & $1.8790^{* *}$ \\
$\alpha \mathrm{k}$ & -0.0461 & -0.0034 & 0.3527 & 0.6159 \\
$\mathrm{~L}$ & 11.8264 & 11.0063 & -0.9725 & -1.1410 \\
$\mathrm{D}$ & 0.9682 & 0.9029 & -0.4804 & 0.7226 \\
$\mathrm{CF}$ & 0.0791 & 0.1437 & $2.3884^{* * *}$ & 1.3895 \\
$\mathrm{HH}$ & 1552 & 2216 & $3.5576^{* * *}$ & $3.8258^{* * *}$ \\
$\sigma \mathrm{V}$ & 1.0017 & 0.6375 & $-6.5193^{* * *}$ & $-6.8092^{* * *}$ \\
$\mathrm{G}$ & 0.6262 & 0.0566 & $-2.9683^{* * *}$ & $-2.4006^{* *}$ \\
\hline
\end{tabular}

This table reports the non-parametric procedure of the Wilcoxon Normal Approximation. Industry is defined by the 2-digit SIC code. $\triangle A$ and $C F$ are meant to proxy for internal capital. $C F$ denotes operating cash flow measured by operating income plus $\mathrm{R} \& \mathrm{D}$ expenditures. $\Delta A$ is the annual change in total assets, a proxy for the net investment component of internal capital. $\Delta S$ is annual change (expected growth) in net sales. $H H$ represents the Herfindhal-Hirschman index, calculated by summing the squares of percent market share of each firm (using sales) in the industry. Both $\Delta S$ and $H H$ are meant to proxy for the expected value of the monopoly rents. $P$ denotes the relative probability of innovation derived as the number of patents divided by the industry number of patents, and $P P$ is stock of patents, computed by dividing cumulative patents within past 17 years by industry stock of patents, both scaled by the ratio of firm assets to industry assets. $\sigma_{\mathrm{v}}$ represents volatility of the growth option, computed as the natural logarithm of the ratio of the 52-week high to 52-week low of the stock price as in Chauvin \& Hirschey (1993) following Garman \& Klass (1980). $K$ denotes capital expenditure, and $\alpha_{\mathrm{k}}$ is the "surprise" or unexpected change in capital expenditures derived as the difference between $\log \left(K_{t+1} / K_{t}\right)$ and $\log \left(K_{t} / K_{t-1}\right)$ where $t$ is current year. $x$ represents R\&D. $y$ denotes rival R\&D obtained by subtracting firm R\&D from industry R\&D, normalized by industry assets. Labor productivity, $L$, is the ratio of total output (net sales) to labor inputs (number of employees). Debt ratio, $D$, is the sum of debt in current liabilities and long-term debt divided by total assets, scaled by industry debt ratio. $G$ denotes the excess market value over replacement cost of the firm, a proxy for growth opportunities, and is computed as the sum of the market value of equity and total debt less total book assets. $\Delta A$, $C F, \Delta S, x, y, K$, and $G$ are all normalized by assets. $1 \%, 5 \%$, and $10 \%$ statistical significance is indicated with ${ }^{* * *},{ }^{* *}$, and ${ }^{*}$, respectively. 
Table 4. Cross-Sectional regression analysis with current patents, $p$, as dependent variable

\begin{tabular}{ccccc}
\hline & \multicolumn{2}{c}{ Emerging Firms } & \multicolumn{2}{c}{ Mature Firms } \\
\hline Variable & Coefficient & t-statistic & Coefficient & t-statistic \\
$I N T$ & -9.417 & 0.004 & 0.048 & 0.333 \\
$E T$ & -1.254 & $-3.212^{* * *}$ & 0.131 & 0.698 \\
$\Delta A_{t+1}$ & 0.147 & 0.213 & 0.641 & 0.887 \\
$\Delta A_{t-1}$ & -0.617 & 0.480 & -0.609 & -0.765 \\
$\Delta S_{t+1}$ & 0.601 & 1.081 & -0.653 & -1.084 \\
$\Delta S_{t-1}$ & 1.534 & 0.657 & 0.940 & 1.465 \\
$P P_{t}$ & 0.554 & $7.356^{* * *}$ & 0.178 & $4.831^{* * *}$ \\
$\Delta P_{t+1}$ & 0.094 & $2.678^{* *}$ & 0.542 & $12.35^{* * *}$ \\
$x_{t}$ & 8.695 & $2.932^{* *}$ & 6.733 & $2.257^{* *}$ \\
$\Delta x_{t-1}$ & 6.057 & 0.681 & -10.51 & $-2.009^{* *}$ \\
$y_{t}$ & -33.10 & -0.290 & -11.17 & -1.534 \\
$\Delta y_{t-1}$ & 1377 & $1.878^{*}$ & 80.86 & 0.894 \\
$K_{t}$ & -0.202 & 0.163 & 0.935 & 0.369 \\
$\Delta K_{t-1}$ & 0.909 & -0.238 & -2.405 & -0.401 \\
$\alpha_{t}$ & 0.040 & 1.071 & -0.073 & -0.344 \\
$L_{t}$ & -0.007 & -1.052 & -0.006 & -0.332 \\
$\Delta L_{t-1}$ & 0.007 & 1.312 & 0.005 & 0.094 \\
$D_{t}$ & -0.193 & -0.645 & -0.017 & 0.935 \\
$\Delta D_{t-1}$ & -0.633 & -0.634 & -0.238 & -0.761 \\
$C F_{t}$ & -1.606 & -1.428 & -0.255 & 0.110 \\
$\Delta C F_{t-1}$ & 1.376 & $1.735^{*}$ & 0.769 & -0.225 \\
$H H_{t}$ & 0.006 & 0.355 & 0.000 & -0.814 \\
$\Delta H H_{t+1}$ & -0.008 & -1.136 & -0.003 & -1.160 \\
$\Delta H H_{t-1}$ & -0.043 & -1.430 & 0.004 & 1.569 \\
$\sigma_{t}$ & -0.619 & -1.314 & -0.066 & -0.565 \\
$\Delta \sigma_{t-1}$ & 0.764 & $2.162^{* *}$ & 0.195 & 1.024 \\
$A d j . R^{2}$ & 0.500 & & 0.682 & \\
$F-S t a t$. & $6.7^{* * *}$ & & $12.1 * *$ & \\
\hline & & & &
\end{tabular}

This table presents the mean coefficients and their t-statistics from Fama-MacBeth regressions run for each year $t$ across all firms. INT denotes intercept and $E T$ is the natural logarithm of the number of years of life of a firm since founded. All other variables are as defined in table 2. A firm must have financial data on all variables in the seven-year sample period, 1987-1993. Future change (one-year) in R\&D is expressed as: $\Delta x_{t+1}=\left(x_{t+1}-x_{t}\right) / A_{t}$. Past change (one-year) in R\&D is expressed as: $\Delta x_{t-1}=\left(x_{t}-x_{t-1}\right) / A_{t}$. Changes (expected values) in all other variables are computed similarly and scaled as defined in table 3, except for $L, \alpha$, and $H H$ which are ratio changes. $1 \%, 5 \%$, and $10 \%$ statistical significance is indicated with ${ }^{* * *},{ }^{* *}$, and ${ }^{*}$, respectively.

\section{Conclusion}

In this study we examine the determinants of patenting of emerging firms, particularly the impact of internal capital markets. As predicted, the empirical results demonstrate that the roles of internal finance in emerging and established firms are significantly different. Based on theoretical arguments, we hypothesize that emerging firms tend to rely more on internal capital as opposed to mature companies that have greater access to external capital markets to finance investment opportunities. This is strongly supported by the empirical results. For emerging firms, operating cash flows and R\&D expenditures are significantly positive. These results are consistent with our hypothesis that internal cash flows are a critical source of financing future growth opportunities, with R\&D being a valuable determinant of patenting since it serves to speed up innovation and shorten the maturity date of the real call option.

However, mature firms show the opposite results: internal cash flows have a negative but not significant influence on patents while past $R \& D$ is negative and significant and current $R \& D$ is positive and significant. A plausible explanation is that the market recognizes available investment opportunity sets for these established firms but may prefer that they purchase ready technology through, for instance, synergistic mergers and acquisitions rather than engaging in risky R\&D investments which have very uncertain payoffs. These results for the mature firms are nevertheless consistent with the dark side view of the internal capital markets theory. 
If growth opportunities were a significant component of the market value of emerging firms, then we would expect acquisition of debt to have a negative impact due to the under-investment hypothesis of Myers (1977). We document that emerging firms have lower debt ratio than mature firms, but this difference is not significant. We also find that debt is negative for emerging firms but positive for mature firms. However, these influences are not significant, further indicating a weaker support for the hypothesis.

Patents are predicted by the model to be a good proxy for the time to maturity of the real option. Thus, we would expect patents to have a positive influence on growth opportunities. Our results show that they are valuable. However, they tend to lose power when controlled for other variables, especially R\&D. Nevertheless, past patents and R\&D have a significantly positive impact on the output of current patents.

Risk of R\&D investments is significantly and positively associated with patenting of emerging firms. However, this association is weaker for mature firms, perhaps due to their ability to diversify, and the fact that their investments may be supported more by existing assets (collateral effect).

\section{References}

Alchian, A. A. (1969). Corporate management and property rights. In Manne, H. (Ed.). Economic Policy and the Regulation of Corporate Securities. Washington, DC: American Enterprise Institute.

Allison, J. R., Tiller, E. H., Zyontz, S., \& Bligh, T. (2012). Patent litigation and the internet. Standford Technology Law Review. Retrieved from http://stlr.stanford.edu/2012/02/patent-litigation-and-the-internet/

Berk, B. J., Green, R. C., \& Naik, V. (1999). Valuation and return dynamics of new ventures. Journal of Finance, 54(5). 1553-1607. http://dx.doi.org/10.1111/0022-1082.00161

Bound, J., Cummins, C., Griliches, Z., Hall, B., \& Adam, J. (1984). Who does R\&D and who patents? In Griliches, Z. (Ed.). R\&D, Patents, and Productivity (pp. 21-54). Chicago: University of Chicago Press

Bower, J. L. (1970). Managing the resource allocation process. Boston: Harvard Business School Press.

Chandler, A. H. (1990, March-April). The enduring logic of managerial success. Harvard Business Review, 1-11.

Coase, R. H. (1937). The nature of the firm. Economica, 4. 386-405. http://dx.doi.org/10.1111/j.1468-0335.1937.tb00002.x

Cockburn, I., \& Griliches, Z. (1988). Industry effects and appropriability measures in the stock market's valuation of R\&D and patents. American Economic Review, 78(May), 419-423.

Dasgupta, P., \& Stiglitz, J. (1980). Uncertainty, industrial structure, and the speed of R\&D. Bell Journal of Economics, 11(1), 1-28. http://dx.doi.org/10.2307/3003398

Duchin, R., \& Sosyura, D. (2013). Divisional managers and internal capital markets. Journal of Finance, 68, 387429. http://dx.doi.org/10.1111/jofi.12003

Fazzari, S. M., \& Athey, M. J. (1987). Asymmetric information, financing constraints, and investment. The Review of Economics and Statistics, 481-487. http://dx.doi.org/10.2307/1925536

Gertner, R. H., Scharfstein, D. S., \& Stein, J. C. (1994). Internal and external capital markets. Quarterly Journal of Economics, 109. 1211-1230. http://dx.doi.org/10.2307/2118361

Glaser, M., Lopez de-Silanes, F., \& Sautner, Z. (2013). Opening the black box: Internal capital markets and managerial power. Journal of Finance, 68, 1577-1631. http://dx.doi.org/10.1111/jofi.12046

Graham, J. R., Harvey, C. R., \& Puri, M. (2011). Capital allocation and delegation of decision-making authority within firms. Working Paper. Duke University. Retrieved from https://faculty.fuqua.duke.edu/ jgraham/resume.html

Griliches, Z. (1979). Issues in assessing the contribution of R\&D to productivity growth. Bell Journal of Economics, 10(Spring), 92-116. http://dx.doi.org/10.2307/3003321

Griliches, Z. (1980). R\&D and the productivity slowdown. American Economic Review, 70(May), 343-348. Retrieved from http://ideas.repec.org/e/pgr23.html

Griliches, Z. (1981). Market value, R\&D, and patents. Economic Letters, 7(2), 183-187. http://dx.doi.org/10.1016/0165-1765(87)90114-5

Griliches, Z., \& Mairesse, J. (1984). Productivity and R\&D at the firm level. In Griliches, Z. (Ed.), R\&D, Patents, and Productivity (pp. 339-374). Chicago: University of Chicago Press. http://dx.doi.org/10.7208/chicago/9780226308920.001.0001 
Hayes, R. H., \& Abernathy, W. J. (1980). Managing our way to economic decline. Harvard Business Review, (July-August), 67-77.

Hitt, M. A., Hoskisson, R. E., \& Ireland, R. D. (1990). Mergers and acquisitions and managerial commitment to innovation in M-form firms. Strategic Management Journal, 11, 29-47.

Jensen, M., \& Meckling, W. (1976). Theory of the firm: Managerial behavior, agency costs, and ownership structure. Journal of Financial Economics, 4, 305-360. http://dx.doi.org/10.1016/0304-405X(76)90026-X

Kamien, I. M., \& Schwartz, L. N. (1980). A generalized hazard rate. Economic Letters, 5, 245-249. http://dx.doi.org/10.1016/0165-1765(80)90039-7

Lamont, O. (1997). Cash flow and investment: Evidence from internal capital markets. Journal of Finance, 52, 83-109. http://dx.doi.org/10.1111/j.1540-6261.1997.tb03809.x

Lee, T., \& Wilde, L. L. (1980). Market structure and innovation: A reformulation. Quarterly Journal of Economics, (March), 429-436. http://dx.doi.org/10.2307/1884551

Lopez-Garcia, J., \& Aybar-Arias, C. (2000). An empirical approach to the financial behavior of small and medium sized companies. Small Business Economics, 14, 55-63. http://dx.doi.org/10.1023/A:1008139518709

Loury, C. G. (1979). Market structure and innovation. Quarterly Journal of Economics, (August), 395-410. http://dx.doi.org/10.2307/1883165

Maksimovic, V., \& Phillips, G. (2002). Do conglomerate firms allocate resources inefficiently across industries? Theory and evidence. Journal of Finance, 57, 721-767. http://dx.doi.org/10.1111/1540-6261.00440

Matsusaka, J. G., \& Nanda, V. (2002). Internal capital markets and corporate refocusing. Journal of Financial Intermediation, 11, 176-211. http://dx.doi.org/10.1006/jfin.2001.0333

Megna, P., \& Klock, M. (1993). The impact of intangible capital on Tobin's q in the semiconductor industry. American Economic Review, 83(May), 265-269.

Milgrom, P. (1988). Employment contracts, influence activities, and efficient organization design. Journal of Political Economy, 96, 42-60. http://dx.doi.org/10.1086/261523

Milgrom, P., \& Roberts, D. J. (1988). An economic approach to influence activities in organizations. American Journal of Sociology, 94, 154-179. http://dx.doi.org/10.1086/228945

Minton, B. A., \& Schrand, C. (1999). The impact of cash flow volatility on discretionary investment and the costs of debt and equity financing. Journal of Financial Economics, 54, 423-460. http://dx.doi.org/10.1016/S0304-405X(99)00042-2

Myers, C. S. (1977). Determinants of corporate borrowing. Journal of Financial Economics, 5, 147-175. http://dx.doi.org/10.1016/0304-405X(77)90015-0

Myers, C. S. (1984). The capital structure puzzle. Journal of Finance, 34(3), 575-592. http://dx.doi.org/10.2307/2327916

Myers, S. C., \& Majluf, N. S. (1984). Corporate financing and investment decisions when firms have information that investors don't have. Journal of Financial Economics, 13, 187-221. http://dx.doi.org/10.1016/0304-405X(84)90023-0

Ottoo, R. E. (1998). Valuation of internal growth opportunities: The case of a biotechnology company. The Quarterly Review of Economics and Finance, 38, 615-633. http://dx.doi.org/10.1016/S1062-9769(99)80093-3

Pakes, A., \& Schankerman, M. (1984). The rate of obsolescence of patents, research gestation lags, and the private rate of return to research resources. In Griliches, Z. (Ed.), R\&D, Patents, and Productivity (pp. 73-88). Chicago: University of Chicago Press.

Rajan, R., Servaes, H., \& Zingales, L. (2000). The cost of diversity: The diversification discount and inefficient investment. Journal of Finance, 55, 35-80. http://dx.doi.org/10.1111/0022-1082.00200

Scharfstein, D. S., \& Stein, J. C. (2000). The dark side of internal capital markets: Divisional rent seeking and inefficient investment. Journal of Finance, 55, 2537-2564. http://dx.doi.org/10.1111/0022-1082.00299

Stein, J. C. (1997). Internal capital markets and the competition for corporate resources. Journal of Finance, 52, 111-133. http://dx.doi.org/10.1111/j.1540-6261.1997.tb03810.x

Stein, J. C. (2003). Agency, information and corporate investment. In Constantinides, G. M., Harris, M., \& Stulz, 
R. (Eds.), Handbook of the Economics of Finance. Amsterdam, Elsevier.

Stulz, R. (1988). Managerial control of voting rights, financing policies and the market for corporate control. Journal of Financial Economics, 20, 25-54. http://dx.doi.org/10.1016/0304-405X(88)90039-6

Weston, J. F. (1970). Mergers and acquisitions in business planning. Rivista Internationale di Scienze Economiche e Commerciali, 17, 309-320.

Williamson, O. E. (1975). Markets and hierarchies: Analysis and antitrust implications. New York: Collier Macmillan Publishers.

Wulf, J. (2009). Influence and inefficacy in the internal capital market. Journal of Economic Behavior and Organization, 72, 305-321. http://dx.doi.org/10.1016/j.jebo.2009.07.001

\section{Copyrights}

Copyright for this article is retained by the author(s), with first publication rights granted to the journal.

This is an open-access article distributed under the terms and conditions of the Creative Commons Attribution license (http://creativecommons.org/licenses/by/3.0/). 